відомих вітчизняних педагогів, учителів-практиків, організаторів трудової підготовки Катеринославщини. У кінці XIX - на початку XX століття були накопичені цінні ідеї, підходи для осмислення і вивчення досвіду у практиці вищої педагогічної школи. Розроблений спецкурс та методичне забезпечення уможливить використання окресленого історико-педагогічного досвіду 3 розвитку трудового навчання Катеринославщини в кінці XIX - на початку XX століття.

\title{
Література
}

1. Державний архів Дніпропетровської області. Ф. 11, оп. 1, Спр. 137. 2. Ємельова А. П. Розвиток трудового навчання в народних школах Катеринославщини (кінець XIX - початок XX століття): навч.-метод. комплекс / А. П. Смельова. - Кривий Ріг, 2013. - 89 с. 3. Методологічні засади педагогічного дослідження: [монографія] / авт. кол. : Є. М. Хриков, О. В. Адаменко, В. С. Курило та ін.; за заг. ред. В. С. Курила, С. М. Хрикова; Держ. закл. «Луган. нац. ун-т імені Тараса Шевченка». - Луганськ : ДЗ «ЛНУ імені Тараса Шевченка», 2013. - 248 с. 4. Отчет Екатеринославской Губернской Земской Управы за 1903 год, Екатеринослав: Типография Губернского Земства. - 1904. - 197 с.

УДК 37.014 .6

олена Кухарук

\section{ГОТОВНІСТЬ ДО МОНІТОРИНГУ ЯК ПЕДАГОГІЧНА ПРОБЛЕМА}

Кухарук О. В. Готовність до моніторингу як педагогічна проблема.

У статті висвітлено проблему готовності майбутніх педагогів до моніторингу. Здійснено грунтовне дослідження основних підходів до визначення сутності поняття «готовність» на основі аналізу психолого-педагогічної літератури. Встановлено сутність поняття «готовність до моніторингу». Виокремлено та охарактеризовано шість взаємопов'язаних структурних компонентів готовності до моніторингу: мотиваційний, науково-теоретичний, когнітивний, оціночний, праксикологічний та психологічний.

Ключові слова: готовність, готовність до моніторингу, мотиваційний, науковотеоретичний, когнітивний, оціночний, праксикологічний та психологічний компоненти.

Кухарук О. В. Готовность к мониторингу как педагогическая проблема.

В статье освещена проблема готовности будущих педагогов к мониторингу. Осуществлено детальное исследование основных подходов к определению сущности понятия «готовность» на основе анализа психолого-педагогической литературы. Установлено сущность понятия «готовность к мониторингу». Выделены и охарактеризованы шесть взаимосвязанных структурных компонентов готовности к мониторингу: мотивационный, научно-теоретический, когнитивный, оценочный, праксикологичний и психологический.

Ключевые слова: готовность, готовность к мониторингу, мотивационный, научно-теоретический, когнитивный, оценочный, праксикологичний и психологический компоненты.

Kukharuk O. V. Readiness to monitoring as a pedagogical problem.

The article deals with the problem of future teachers to monitor. Conducted thorough research of the main approaches to defining the essence of the concept of «readiness» based 
on analysis of psychological and educational literature. The essence of the concept of «readiness for monitoring». Allocated and describes the six interrelated structural components readiness monitoring: motivational, scientific-theoretical, cognitive, evaluative, psychological and praksykolohichnyy.

Keywords: readiness, readiness for monitoring, motivation, scientific-theoretical, cognitive, evaluative, praksykolohichnyy and psychological components.

Науково-технічний прогрес, безсумнівно, зумовлює подальше зростання значущості загальної освіченості будь-якої нації, ролі вищої освіти в суспільстві. Найбільш видатні досягнення в економічному розвитку сучасних країн тісно пов'язані з успіхами в галузі вищої освіти.

Зміни соціальних, економічних умов життя України не обминули й систему вищої освіти, що вимагає нових підходів у вивченні й осмисленні педагогічного процесу у вищому навчальному закладі.

Суспільство двадцять першого століття чекає на вчителя, який володіє системою професійних знань і умінь, еміє підтримувати рівень психолого-педагогічної та фахової підготовки, ознайомлений iз новітніми досягненнями q науковопедагогічними дискусіями на національному s світовому рівнях, прагне до постійного саморозвитку та самовдосконалення, тобто є готовим до педагогічної діяльності.

Аналіз педагогічних, психологічних та філософських наукових джерел свідчить про те, що досліджувана проблема розглядається науковцями з різних аспектів.

Проблему формування професійної готовності до педагогічної діяльності розглядають такі дослідники, як: К. Дурай-Новаковська, М. Кобзев, А. Міщенко, В. Тамарін, В. Сластенін та ін.

Вітчизняна педагогіка уже має певні дослідження проблем професійної готовності вчителя до таких видів діяльності:

- до самостійної творчої діяльності (О. Кривильова);

- до комунікації вчителя 3 молодшими школярами засобами образотворчого мистецтва (О. Макарова);

- до виховної роботи в школі (Л. Бродська);

- до особистісно зорієнтованого навчання молодших школярів (Ю. Шаповал);

- до організації освітньо-дозвіллєвої діяльності учнівської молоді (С. Пащенко);

- до різних видів власне професійної діяльності: полікультурної (Я. Гулецька, О. Мілютіна); виховної (І. Василенко, О. Волошина, О. Матієнко, М. Рудь); діагностувальної (О. Мельник, І. Гавриленко, О. Дмитрук, О. Козловська); проектної (М. Елькін, О. Колесніков, Т. Шапошнікова).

Проблему готовності майбутніх вчителів інформатики до моніторингу навчальних досягнень учнів профільної школи досліджувала Н. Мазур. Питаннями про критерії оцінювання роботи керівників загальноосвітніх навчальних закладів на основі готовності до здійснення моніторингу якості освіти займався В. Приходько.

Аналіз психолого-педагогічної літератури свідчить, що на сучасному етапі наука потребує розроблення проблеми формування готовності до моніторингу.

Mema cmammi полягає у визначенні сутності поняття «Готовність до моніторингу» на основі аналізу основних підходів у психолого-педагогічній літературі та виокремленні структурних компонентів готовності до моніторингу.

Професійна підготовка майбутніх педагогічних працівників повинна бути спрямована на розвиток їхньої готовності до професійної діяльності, до оволодіння інформаційними технологіями, до комунікації (спілкування 3 колективом і різними 
категоріями студентів) тощо. Ефективність педагогічної діяльності залежить від уміння вчителя аналізувати іiі результати, визначати на основі певних вихідних умов ефективні методи та засоби навчання, а це вимагає умінь проводити моніторингові дослідження.

Для визначення сутності поняття «готовність до моніторингу» здійснено аналіз поглядів науковців, які проводили дослідження в цьому напрямку.

Тлумачення поняття «готовність» науковцями та дослідниками

Таблиия 1

\begin{tabular}{|c|c|c|}
\hline $\begin{array}{l}\text { № } \\
\text { ПI/II }\end{array}$ & $\begin{array}{c}\text { Прізвище, ініціали } \\
\text { науковців та } \\
\text { дослідників }\end{array}$ & Визначення поняття «готовність» \\
\hline 1 & $\begin{array}{l}\text { М. Дьяченко, } \\
\text { Л. Кандибович } \\
{[4, \text { с. } 27]}\end{array}$ & $\begin{array}{l}\text { «Спрямованість» особи, установка на певну дію. Готовність, } \\
\text { на думку авторів, це налаштування можливостей особистості } \\
\text { для успішної дії у певний момент, внутрішнє налаштування } \\
\text { особи на певну поведінку при виконанні навчальних і } \\
\text { трудових завдань, установка на активні дії. }\end{array}$ \\
\hline 2 & I. Машук [6] & $\begin{array}{l}\text { Це особливий психічний стан, зумовлений комплексом } \\
\text { об'єктивних та суб'єктивних чинників, який характеризується } \\
\text { оптимальною мобілізацією всіх ресурсів організму й } \\
\text { утворюється внаслідок розвитку сукупності особистісних } \\
\text { якостей та завдяки цілеспрямованій підготовці особистості. }\end{array}$ \\
\hline 3. & В. Лєбедєв [6, с. 30] & $\begin{array}{l}\text { Готовність не є перенесенням якостей у нову ситуацію,на } \\
\text { ïх актуалізацію роблять уплив і ті конкретні умови, у яких } \\
\text { здійснюється діяльність. }\end{array}$ \\
\hline 4 & $\begin{array}{l}\text { С. Бризгалова } \\
{[1, \text { с. } 32]}\end{array}$ & $\begin{array}{l}\text { Цілісне особистісне динамічне утворення, набуте в } \\
\text { результаті спеціального навчання, яке містить у своїй } \\
\text { структурі взаємопов'язані елементи: науково-теоретичний, } \\
\text { практичний та психологічний. }\end{array}$ \\
\hline 5 & $\begin{array}{l}\text { Н. Іпполітова } \\
{[5, \text { с. } 117]}\end{array}$ & $\begin{array}{l}\text { Це складна інтеграційна освіта, активно-дієвий суб’єктивний } \\
\text { стан особи, що характеризує мобілізацію сил для виконання } \\
\text { поставленого професійного педагогічного завдання. }\end{array}$ \\
\hline 6 & $\begin{array}{l}\text { К. Дурай- } \\
\text { Новакова [3, с. 35] }\end{array}$ & $\begin{array}{l}\text { Цілісне вираження всіх підструктур особистості, зорієнтованих } \\
\text { на повне та успішне виконання різних функцій учителя. } \\
\text { Професійна готовність - це складне структурне утворення, } \\
\text { центральним ядром якого є позитивні установки, мотиви } \\
\text { та інтеріоризовані цінності учительської професії. }\end{array}$ \\
\hline 7 & А. Деркач [2, с. 8$]$ & $\begin{array}{l}\text { Цілісний вияв властивостей особи, розвиток готовності } \\
\text { означає організацію системи } 3 \text { накопичення суспільної } \\
\text { інформації, стосунків, поведінки тощо, що, активізуючись, } \\
\text { здатне забезпечити індивіда можливістю ефективно } \\
\text { виконувати свої функції. }\end{array}$ \\
\hline 8 & В. Крутецький [6] & $\begin{array}{l}\text { Синтез якостей особистості, які визначають їі придатність } \\
\text { до діяльності. }\end{array}$ \\
\hline
\end{tabular}

На нашу думку, варто виокремити три підходи до визначення поняття «готовність» різними дослідниками та науковцями:

- готовність як стан людини (прихильники - І. Машук, Н. Іпполітова);

- готовність як сукупність індивідуальних якостей особистості (прихильники М. Дьяченко, Л. Кандибович, В. Лебедєв, А. Деркач, В. Крутецький); 
- готовність як складне особистісне утворення, орієнтоване на професійні мотиви (прихильники - С. Бризгалова, К. Дурай-Новакова).

Для здійснення грунтовного дослідження доцільно детальніше розглянути погляди дослідників та науковців щодо тлумачення поняття «готовність».

Дослідниця Н. Іпполітова не враховує об'єктивні чинники при визначенні поняття «готовність». І. Машук зазначає, що готовність характеризується оптимальною мобілізацією всіх ресурсів організму, однак не вказує мети здійснення такої мобілізації. Такою метою може бути виконання поставлених професійних завдань.

Науковці М. Дьяченко, Л. Кандибович розглядають готовність як налаштування можливостей особистості для успішної дії в певний момент. Проте ми вважаємо, що доцільно розглядати готовність як комплекс індивідуальних якостей особистості для постійного виконання професійних задач. Дослідник В. Лєбедєв наголошує на важливості впливу конкретних умов, в яких здійснюється діяльність, але не враховує, що готовність формується в результаті спеціального навчання.

Науковець А. Деркач зосереджує увагу на накопиченні суспільної інформації, яка в майбутньому надасть можливість особистості ефективно виконувати свої функції. Накопичення суспільної інформації $є$ важливим фактором, однак, на нашу думку, формування готовності особистості неможливе без наявності спеціальних знань професійної сфери. Науковець В. Крутецький характеризує готовність як синтез якостей особистості. Проте не менш важливим є установка особи на активне виконання професійних задач.

Дослідниці К. Дурай-Новакова та С. Бризгалова зосереджують увагу на важливості спеціальної професійної підготовки, але недостатньо окреслюють значущість індивідуальних якостей особистості під час визначення поняття «готовність». Також на формування готовності особистості до діяльності впливає внутрішня мотивація для здійснення активних дій.

Проаналізувавши наукові погляди різних дослідників на тлумачення поняття «готовність», варто зазначити, що ми розуміємо під цим терміном. Отже, готовність, на нашу думку, становить характеристику особистості, яка виявляється як система професійних знань та індивідуальних властивостей і здатна реагувати на внутрішні установки людини через виконання професійних завдань.

Для визначення сутності поняття «готовність до моніторингу» потрібно охарактеризувати поняття «моніторинг».

На нашу думку, моніторинг доцільно визначити як систему заходів, спрямованих на отримання об'єктивної інформації шляхом безперервного комплексного відстеження за станом та діяльністю освітньої системи задля забезпечення іiі повноцінного функціонування i прогнозування розвитку за рахунок постійного коригування та прийняття рішень на рівні адміністрації (управління). Система вище вказаних заходів містить організацію, збирання, опрацювання, систематизацію, аналіз, узагальнення, оцінювання, інтерпретацію та поширення інформації.

На основі вказаних вище тлумачень понять «готовність» та «моніторинг» ми визначили зміст поняття «готовність до моніторингу», синтезувавши результати наших досліджень. Отже, готовність до моніторингу ми розуміємо як специфічну професійну характеристику особистості, яка передбачає комплекс спеціальних знань 3 відстеження, прогнозування, корегування, розвитку та прийняття рішень, специфічних індивідуальних якостей i накопиченої суспільної інформації, що мобілізується при виникненні внутрішньої мотивації особи для активного виконання професійних задач. 
Проблему формування готовності до моніторингу, на нашу думку, можна розв'язати визначенням iï структурних компонентів. Тому варто проаналізувати дослідження науковців, які займаються проблемами готовності.

Дослідження зафіксували те, що така готовність, окрім загальних структурних компонентів (когнітивного, мотиваційного, операційного, особистісного тощо), характеризується конкретним змістовним наповненням, яке відтворює особливості процесу моніторингу загалом.

Також у структурі готовності науковці виокремлюють такі компоненти: організаційний (О. Сафоненко), ціннісно-мотиваційний (Т. Таскаєва), поведінковий (М. Рябова), міжособистісний (Л. Мілованова), когнітивний (І. Шеханіна), методологічний (А. Капаєва) тощо.

Розглядаючи структуру готовності, доречно розглянути наукові результати дослідників М. Дьяченко та Л. Кандибович. У змісті структури готовності науковці зосереджують увагу на таких взаємопов'язаних між собою компонентах [1]:

- мотиваційний - виражається в наявності потреби успішно виконувати поставлену задачу, інтересі до об'єкту діяльності, способах її здійснення, прагнення до успіху;

- орієнтаційний - охоплює знання та уявлення про особливості та умови діяльності;

- операціональний - передбачає володіння способами та прийомами діяльності, вміннями та навиками;

- вольовий - характеризує внутрішню потребу в управлінні діями;

- оціночний - передбачає самооцінку свої підготовленості і відповідності процесу розв'язання професійних задач установленим зразкам.

У структурі професійної готовності дослідниця К. Дурай-Новакова виокремлює п'ять компонентів: мотиваційний, пізнавально-оцінний, емоційно-вольовий, операційно-дієвий, мобілізаційний [3].

Науковець Н. Яковлева у якості компонентів пропонує визначати змістовнопроцесуальний, мотиваційно-цільовий, емоційно-моральний.

Згідно 3 науковими поглядами дослідника В. Сластьоніна, професійнопедагогічна готовність - це складний синтез п'яти взаємопов'язаних структурних компонентів [6]:

- психологічна готовність (сформована спрямованість на педагогічну діяльність, установка на роботу в школі);

- науково-теоретична готовність (наявність певного обсягу педагогічних, психологічних, соціальних знань, необхідних для компетентної педагогічної діяльності);

- практична готовність (наявність сформованих на належному рівні професійних знань і вмінь);

- психофізіологічна готовність (наявність відповідних передумов для оволодіння педагогічною діяльністю, сформованість професійно значущих якостей);

- фізична готовність (відповідність стану здоров'я та фізичного розвитку вимогам педагогічної діяльності та професійної працездатності).

У свою чергу, Н. Іпполітова у структурі готовності майбутнього вчителя до професійної педагогічної діяльності виокремлює три взаємопов'язані компоненти [5]:

- особистісний - характеризує ступінь морально-педагогічної готовності вчителя до професійної діяльності, відображає ступінь сформованості ціннісних орієнтацій, інтересу до професії, рівень розвитку мотивації педагогічної діяльності; 
- когнітивний компонент відображає інформованість педагога про сутність та зміст педагогічної діяльності, рівень загальнопедагогічних, методичних, спеціальнопредметних знань, необхідних задля ефективної професійно-педагогічної діяльності;

- праксикологічний компонент характеризує професійні вміння і навички, які необхідні для реалізації функцій педагогічної діяльності та забезпечення іiі ефективності.

Кожне 3 вище зазначених формулювань структури готовності до професійної діяльності є частково або повною мірою обгрунтованим та має право на існування. Однак нас цікавить процес готовності до моніторингу та іiі структурні компоненти. Тому на основі узагальнення наукових поглядів науковців на структуру готовності ми скомпонували структуру готовності майбутніх педагогів до моніторингу, яку представлено на рисунку 1.

Структура готовності майбутніх педагогів до моніторингу містить 6 взаємопов'язаних компонентів.

Мотиваційний компонент - виражається у наявності потреби здійснення успішного та об' єктивного моніторингу задля прогнозування подальшого розвитку системи.

Науково-теоретичний компонент - зумовлює наявність певного обсягу педагогічних, психологічних, соціальних знань, необхідних для ефективної організації моніторингових досліджень.

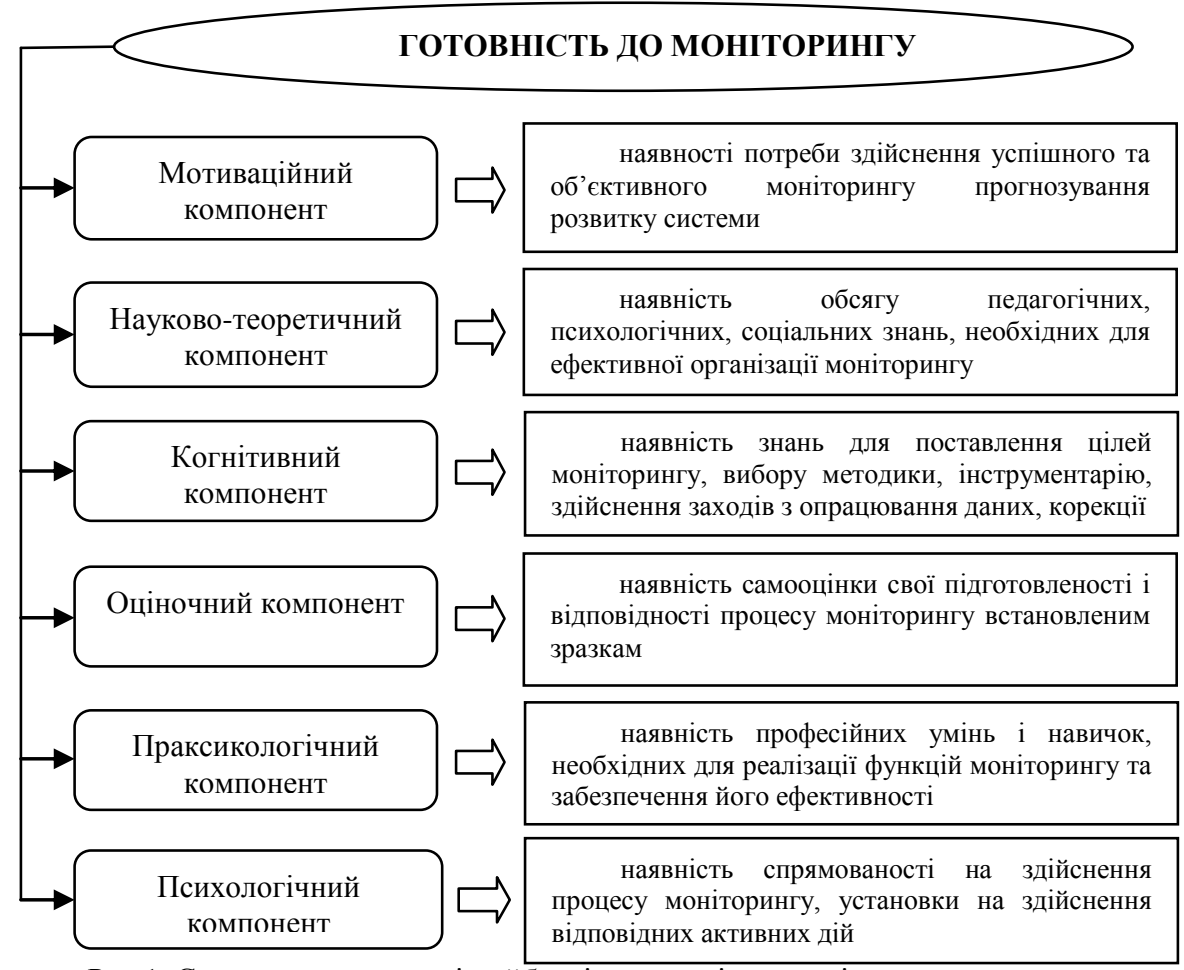

Рис 1. Структура готовності майбутніх педагогів до моніторингу 
Когнітивний компонент відображає наявність знань задля поставлення цілей моніторингу, вибору методики проведення, відповідного інструментарію, здійснення спеціальних заходів з опрацювання інформації, здійснення корекції.

Оціночний компонент - передбачає самооцінку свої підготовленості і відповідності процесу проведення моніторингу встановленим зразкам.

Праксикологічний компонент - характеризує професійні вміння і навички, які необхідні для реалізації функцій моніторингу та забезпечення його ефективності, задля прийняття відповідних управлінських рішень.

Психологічний компонент - окреслює спрямованість на здійснення процесу моніторингу, установку на здійснення відповідних дій.

Отже, готовність до діяльності є одним із критеріїв результативності процесу підготовки. Ї̈̈ розуміють як стан особистості, як систему індивідуальних властивостей, якостей особистості та як складне особистісне утворення, зорієнтоване на професійні мотиви. Ми вважаємо, що структура готовності до моніторингу містить 6 компонентів: мотиваційний, науково-теоретичний, когнітивний, оціночний, праксикологічний та психологічний. Усі компоненти структури готовності до моніторингу взаємопов'язані та не можуть існувати окремо.

\section{Література}

1. Брызгалова С. И. Формирование в вузе готовности учителя к педагогическому исследованию: теория и практика / С. И. Брызгалова. Калининград, 2004. - 312 с. 2. Деркач А. А. Акмеологические основы развития профессионала / А. А. Деркач. - М. : Воронеж, 2004. - 752 с. 3. ДурайНовакова К. М. Формирование профессиональной готовности студентов к педагогической деятельности : автореф. дис. на соискание ученой степени канд. пед. наук / К. М. Дурай-Новакова. - М., 1983. - 32 с. 4. Дьяченко М. И. Психологические проблемы готовности к деятельности / М. И. Дьяченко, Л. А. Кандыбович. - Минск: Изд-во БГУ, 1975. - 173 с. 5. Ипполитова Н. В. Система профессиональной подготовки студентов педагогического вуза: личностный аспект: монография [Текст] / Н. В. Ипполитова, М. А. Колесников, Е. А. Соколова. - Шадринск: Исеть, 2006. - 236 с. 6. Сластенин В. А. Педагогика : [учебн. пособ. для студ. высш. пед. учеб. завед.] / $\quad$ В. А. Сластенин, И. Ф. Исаев, Е.Н. Шиянов; под ред. В. А. Сластенина. - М. : Изд. центр «Академия», 2002. - 576 с.

\section{ПЕРШІ ПРОГРАМИ «ВИХОВАННЯ ХАРАКТЕРУ» В АМЕРИКАНСЬКІЙ ШКОЛІ ТА ЇХ ОСОБЛИВОСТІ}

Олішкевич С. В. Перші програми «Виховання характеру» в американській школі та їх особливості.

У статті проаналізовано основні тенденції XX століття та їх уплив на розвиток виховання характеру, виокремлено дві провідні організації («Бойскаути Америки» та «Християнська Молодіжна Асоціація»), які першими почали займатись вихованням характеру в США, а також зображено шлях, який вони пройшли перед тим, як потрапили до американських шкіл і стати невід'ємним складником навчального процесу.

Ключові слова: програма «Виховання характеру», бойскаути, «Бойскаути Америки», «Християнська Молодіжна Асоціація», виховання. 